Коломієць Н. $\boldsymbol{\epsilon}$,

кандидат філологічних наук, доцент кафедри української та світової літератур ДВНЗ «Криворізький державний педагогічний університет»

\title{
ІРРАЦІОНАЛЬНЕ В ХУДОЖНІЙ МОДЕЛІ СВІТУ РОМАНУ «ЗАЗИРНИ В МОЇ СНИ» МАКСА КІДРУКА
}

У статті зроблено спробу дослідити специфіку ірраціонального в художній моделі світу роману «Зазирни в мої сни» сучасного украӥнського письменника Макса Кідрука. Значну увагу приділено характеристиці оніропростору твору. Простежено особливості художнього відтворення фізіологічних трансформачій персонажів, корелячію «свого» $i$ «чужого» $y$ свідомості людини; окреслено специфіку трансиендентної міри часу.

Ключові слова: містика, оніросфера, технотрилер, психічні стани та процеси.

The article attempts to investigate the specificity of the novel «Look Into My Dreams» by moder Ukrainian writer Max Kidruk, which is irrational in the art model of the world. Considerable attention is paid to the characterization of the onyric space of the work. In the article we traced: the specialities of the artistic reproduction of the physiological transformations of the characters, the correlation of «one's own» and «another's» in the mind of a person are traced; psychological states and processes.

Key words: mysticism, onyrosphere, technotriller, mental states and processes.

B статье сделана попытка исследовать специфику иррационального в художественной модели мира романа «Загляни в мои сныл» современного украинского писателя Макса Кидрука. Значительное внимание уделено характеристике онирического пространства произведения. Прослежены особенности художественного воспроизведения физиологических трансформаций персонажей, корреляция «своего» и «чужого» в сознании человека; определена специфика трансиендентной меры времени.

Ключевые слова: мистика, ониросфера, технотриллер, психические состояния и прочессы.

Художнє осмислення феномену ірраціонального набуває актуальності в контексті досягнень науково-технічної сфери, трансформації світоглядних i ціннісних орієнтирів суспільства. О. М. Хмелевська стверджує, що «іррачіональне в суспільній свідомості історично притаманне людству як на початковому етапі сочіокультурного розвитку, так $і$ в сучасності, в поєднанні з науковим світоглядом. У намі дні ірращуіональні образи користуються популярністю i стають надбанням масової культури» [Хмелевская 2001:3]. Ірраціональне постає специфічним кодом, що дозволяє художньо передати неможливі в реальному житті ситуації та процеси. Воно лежить в основі 
фантастичного допущення, дозволяє конструювати художній світ творів, який моделюється як химерна, апріорі ірреальна дійсність.

У романі сучасного українського письменника Макса Кідрука містичне допущення спирається на новітні наукові концепції, зокрема застосовуються досягнення фізики, хімії, психології, медицини. Для вимірювання явищ, що протікають на безсвідомому рівні психіки людини, письменник використав неіснуючу технологію мозкового сканеру, висунувши у післямові припущення про можливість появи у майбутньому побідних пристроїв [Кідрук 2016:519]. Твір має характерні для технотрилеру риси: «гостросюжетність, динамічність сюжету, ескейпізм; використання документальності $i$ наукових даних; боротьба з технологічними небезпеками. Психотрилер має свої «константи»: наявність психологічного й емочуйного конфлікту, а не фізичного, а також боротьба з суперником; вирішення загадок, пошуки, спроби осягнення таємницьь, містичні мотиви» [Костецька 2015:135].

Організуючим центром образної системи твору $\epsilon$ оніризм. Панораму містичного простору роману створюють картини сновидінь, їх дешифровка, припущення про наслідки клінічної смерті, сомнамбулістичні блукання. Пролептичні сновидіння у творі містять певні натяки, вказівки на можливий розвиток подій, що додатково підсилює містичну складову роману.

Клінічна смерть дворічного хлопчика Теодора тривала 36 секунд. Але зміни, що відбулись перетворили його на «ошалілого монстра» [Кідрук 2016:476]. Через два роки після операції батько починає усвідомлювати, що син «...повернувся не сам. Щось учепилося в нього, коли він перебував там - по той бік лінії, яку більшість із нас перетинає лиш один раз. Упродовж тих тридияти шести секунд щуось схопило мого сина за руку та повернулося разом із ним» [Кідрук 2016:31]. Термінальний стан хлопчика $\epsilon$ складовою архетипної структури смерть-народження. Пробудження після зупинки дихання трактується автором не як відновлення Тео після півхвилинної відсутності, а як прихід у світ невідомої субстанції (чи то пам’яті, чи то підсвідомості іншої людини), що несе руйнацію особистості, жахи, 
галюцинаторні видіння. Відновлення зовнішніх проявів життєдіяльності одразу після операції відбулося повноцінно. Неодноразові медичні обстеження та постреанімаційні заходи переконали батьків у задовільному стані здоров’я сина.

Хворобливий стан свідомості пізніше проявив себе у мареннях, які викликали жахливу реакцію хлопця та супроводжувалися криком: «...він кричить, він безперервно верещить... із ним щзось не так, такого щуе не було ... він прокинувся і кричить, нібито... я не знаю, щзо з ним» [Кідрук 2016:34]; «Тео кричав уві сні ц̌ довго не прокидався» [Кідрук 2016:52]; «Вереск долинав 3 кімнати Теодора <..> Просто не міг усвідомити, щзо малюк, якому не виповнилося трьох років $i$ який важить трохи більше ніж одинадцять кілограмів, здатен видавати такі страшні ци розкотисті звуки» [Кідрук 2016:40]; «Було щзось жахливе в тому верещуанні. Подумалося, щзо так кричать герої фільмів про екзоричзм, із яких виганяють злих духів» [Кідрук 2016:40-41]. В описах дитячого плачу домінують повтори дієслів «кричить», «верещить», які утворюють звуковий образ, розкривають протікання захисної реакції хлопчика на стрес, що наносить організму зміст сновидінь.

Автор акцентує на змінах у поведінці дитини. Зокрема вказує, що до безсонних ночей додалися «провали», коли Теодор застигав на певний час (декілька секунд), зовсім не реагував на подразники. Увагу дитини в таких ситуаціях не вдавалося привернути нікому з рідних. Напади траплялись і під час гри вдома, і під час прогулянок. Вони тривали недовго і Тео знову повертався до свого заняття.

Сон у творі стає важливою складовою ірраціонального буття: «Нам здавалося, щзо сутність, яка оселилась у снах Теодора, існує наче в паралельному світі, щзо той світ навіть теоретично неспроможний перетнутися з нашим - тобто перетнутися безпосередньо, напряму, а не через Теодора, - i щзо ми лише спостерігачі, які завдяки розробкам Енді Даллтона отримали можливість зазирнути в те примарне хтозна-де» [Кідрук 2016:392]. Автор прагне надати наукового тлумачення змінам в поведінці хлопчика, який пережив клінічну смерть. Письменник намагається декодувати таїну сновидінь 
завдяки вкрапленню динамічного техно: наукові розвідки доктора Е. Даллтона дозволили стежити за сигналами людського мозку та бачити нічні видіння іншої людини. Таким чином марення стали площиною комунікації. Завдяки цьому винаходу розкрили доставку наркотиків із Колумбії, попередили про вашингтонський теракт.

У творі відбито процес розшифрування візуального вмісту сну, що представлений різними фазами. Одна 3 них містить ті явища, які відбувались наяву. Зокрема, перед сном батько читав хлопчику книгу, в якій була ілюстрація авіагоризонту, що трансформувалась уві сні: «Спочатку нестійкими й через те немовби живими плямами проступили кольори - сірий, білий, темно-сірий $i$ жовтий. За мить плями змішалися, породивщи сферу, верхня половина якої залишалася блакитною, а нижня - коричневою. Паралельні білі риски розбігалися вгору ц̌ униз від лінї поєднання кольорів» [Кідрук 2016:394]. Застосування технології мозкового сканеру дозволило простежити трансляцію та перетворення зорового образу в оніропросторі. У цій візуалізації художньо трансформовано трансцендентну міру часу. Т. С. Бовсунівська стверджує: «Ця особлива міра часу притаманна оніричній сфері людського буття, в якій трансиендентне проступає хоча $і$ в зримих формах, але ірреального образу. Сон як відчуження людини від себе самої й споглядання себе як Іншого стає способом дидактичного розвитку відчуття трансцендентного кожною людиною. Час у оніропросторі є динамічним, може миттєво прискорюватись, як $і$ навпаки, уповільнюватись, щуо, врешті, залежить лише від активності переживання героєм (чи групи персонажів) подій сну. Час у оніропросторі $\epsilon$ настільки неконтрольованою категорією, щуо аналіз часопросторових змін у художньому фрагменті якогось видіння чи марення може дати водночас кільканадиять часових векторів і водночас жодного ймовірно реалістичного» [Бовсунівська 2015:196]. Усі присутні в кімнаті для спостережень завдяки графіці електричної активності мозку мали можливість бачити сон очима хлопчика: «...Теодор уві сні мчить геть, а коридор секунду потому вицвітає й розповзається, закручується вихорами, ніби вихлюпнута у коловоріт фарба» 
[Кідрук 2016:398]. Динаміка сновидіння передана дієслівним рядом «мчить», «вицвітає й розповзається», «закручується» та ін.

Підсвідомість Тео постійно витворює образ чоловіка 3 випеченим ромбом на щоці. Ним виявився мексиканський наркоторговець Матео Кампо, якого вбили в той самий час, коли в Тео на операції зупинилося серце. «3 якоїсь причини він не потрапив туди, куди йдуть після смерті (хай там, де люди мають опинитися - в раю, пеклі чи якому-небудь чорному ніщцо), після чого почав приходити до мого сина вві сні. Зрештою немає нічого дивного в ідеї, щзо помираючи, ми помираємо не повністю» [Кідрук 2016:426]. Усвідомлення можливості подібного злиття викликає в батька хлопця страх, адже саме сновидіння є джерелом для інтерпретації підсвідомих процесів.

Раціонального прояснення тому, як долі цих людей переплелися не було. Існувало лише містичне припущення: «24 листопада 2012-го сери̧е Теодора зупинилося строго водночас із серизем Матео Кампо і щзо, крім них, тієї секунди y світі більше ніхто не помер. Напевно, цее якось пов'язало їх, $і$ вони разом рушили туди, куди ми всі йдемо після смерті, а потім Тео повернувся, щзо дало змогу повернутися Даймонду. Не зовсім, звісно, повернутися, бо повертатися він уже не мав куди..» [Кідрук 2016:452-453]. Ця людина вмерла, але з’являлася в снах хлопчика, викликаючи істерики, неспокій, сльози.

Свідомість батька відносно метаморфоз, що відбуваються із сином, породжує бінарну опозицію «свій - чужий». «Чужий» у його сприйнятті трактується як «інший», «потойбічний», «невідомий». Болісний процес руйнації людської особистості через наявність інорідної сутності метафоризується в тексті: «3 нього не вилазив чужий чи щзось таке» [Кідрук 2016:436]. Неприйняття сторонньої субстанції в тілі своєї дитини підкреслюється в описі зовнішності: «Його порожнисті, нічим не наповнені очі - $i$ цуе вклинилося $y$ пам'ять найдужче - нагадували оточені чорною грязюкою провалля. Ті очі були не його» [Кідрук 2016:403]. Митець неодноразово звертається до опису очей 3 метою точнішої передачі фізичного та психічного стану хлопця: «його очі залишалися порожніми ц̌ пласкими, неначе два великі гудзики» 
[Кідрук 2016:387], «повіки сина були напівопущені. Очні яблука асинхронно сіпалися, так сильно, що від їхніх рухів тріпотіли вії, проте в щілинах під повіками проступали лише білки» [Кідрук 2016:41], «його очі виглядали водянистими та ніби якимись розмазаними» [Кідрук 2016:456] та ін. Організовані таким чином художні деталі відбивають нервовий розлад, психічно-фізичну деформацію особистості. Епітети («порожні», «пласкі», «водянисті», «розмазані» та ін.) вказують на внутрішню порожнечу, спустошеність, некерованість психо-фізичних реакцій.

Надприродне в поведінці хлопця лише підсилює жах: «Щось додало йому сили, тож він легко дострибнув до грудей. Істота, щьо годину тому була моїм сином, учепилася лівою рукою в мою сорочку, а ногами вперлася мені в живіт» [Кідрук 2016:404]. У роздумах батька над наявністю «чужого» домінує екзистенціал відчаю, породжений відсутністю раціонально-визначеної опори. Коли він мав можливість бачити сни Тео, бути ніби співучасником подій, то відчував страх, що має невротичну форму: «скажений ірращіональний страх охопив мене» [Кідрук 2016:398]. Поступово жах посилювався, як посилювалось і відчуття присутності «чужого»: «А щу як ще вже не мій син? - із жахом подумав я. Що як від мого Тео лишилася лиш оболонка? Даймонд нікуди не подівся, він постійно поруч - $i$ вдень, $i$ вночі, - то, можливо, таки варто боятись?» [Кідрук 2016:444]; «Нестерпне відчуття, щэо переді мною не мій син, зринуло знову» [Кідрук 2016:456] та ін.

Між Теодором і Даймондом виник зв'язок і фактично стерлась межа між сном і дійсністю. Перебуваючи в тілі хлопчика, останній міг передавати інформацію і фактично підкорив собі свідомість дитини. Коли він захотів покинути землю, то почав готувати хлопця до переходу та обирати знаряддя смерті (ніж, фенол та ін.). У діалозі з батьком син розповів, що Даймонд хоче піти, що це не буде боляче, що «чужому» тут не подобається. Після випадку на шосе стало зрозуміло, що порятунок і спокій «чужий» знайде лише тоді, коли вб’є дитину. Тому вирішили ввести Тео в стан контрольованої клінічної смерті. Цю ідею сформулювала Ліза як єдино можливий варіант збереження життя 
хлопчика: «Клінічна смерть не протриває ц̌ хвилини, ми майже відразу «повернемо» Теодора до життя. Я розумію, о’кей, цฺе страшно, ми наблизимо вамого малюка до дуже небезпечної межі, та погляньмо правді у вічі: нам немає з чого вибирати. Я не уявляю, як інакше розірвати зв'язок між Матео Кампо й Теодором <..> Ми мусимо дати йому піти, Мироне. Сам по собі Даймонд не залишить вашого сина у спокої» [Кідрук 2016:477].

Коли відбулося відновлення функцій організму, визначились із перевіркою висунутої гіпотези. Дві ночі хлопчик засинав у шапці 3 мікроелектродами на голові і у сні «навіть натяку на антропоморфну фігуру не було» [Кідрук 2016:494]. Спостереження за поведінкою сина, аналіз бесід про його сновидіння дозволили батькові зробити висновок про відсутність чогось стороннього у свідомості хлопчика та дали надію на повернення до повноцінного життя. Та ніч у Hunter's Creek Hotel довела передчасність оптимістичних висновків. Мирон помітив відсутність сина у ліжку, пошуки привели на дах.

Зовнішність хлопчика дивувала. Для підсилення ефекту сюжетного напруження в портретній характеристиці застосовано деталізацію: «Тео мовчав - губи міщуно стиснуті, кутики їх опущуені, - хоча з цุим проблеми не було. Проблема була з очима. Вони здавались величезними - такими, ніби хлопчак роздивлявся мене крізь окуляри із двозначними діоптріями. Я мусив тричі зморгнути, щуоби збагнути, щуо цฺе лище ілюзія, спричинена неймовірним розииренням райдужних оболонок. 3 якогось дива райдужки розрослися майже до розмірів очного яблука. Щоправда, не це лякало понад усе. Ті гіпертрофовані райдужки були иілковито чорними з країв сріблястими, мов ртуть, у середині» [Кідрук 2016:511]. Екстремальна ситуація увиразнюється за допомогою кольорового психологізму. Чорнота очей несе додаткове символічне навантаження. За допомогою сріблясто-чорно кольорової гами митець увиразнив жах, передав емоційне напруження хлопця.

Хронотопний локальний маркер ЛЕП $\epsilon$ важливою інформативною деталлю. Лінії ЛЕП ще вдень привернули увагу Тео. Щоб потрапити на дах він 
подолав більш як метрову металеву огорожу - «практично неподоланний бар'єр для того, чий зріст не так давно перевищчив сто сантиметрів» [Кідрук 2016:510]. Переживання батька через усвідомлення загрози життю сина у зв’язку 3 перебуванням біля дротів ЛЕП передано метафорами: «страх паралізував мене», «серцее раз у раз підскакувало та зависало, заливаючи груди моторошною порожнечею» [Кідрук 2016:512]. Дотик до дроту високої напруги вирішив ситуацію, все скінчилось раптово.

Жах пережитого викликав страшний крик Мирона: «...із горла із сухим закостенілим скрипом вирвався периий крик. За ним пішов другий, третій, четвертий - щуораз сильніші. Я кричав знову й знову, вивергав із себе крики, нібито плювався вогнем, і нічого не міг удіяти, щзоб погасити той вогонь, бо надходив він не з тіла, а з чогось глибшого, позбавленого оболонки $i$ схованого поміж легень, з чогось, щзо на відміну від тіла усвідомлювало, щзо його навіки покалічено. Я волав так, що міг добудитися мертвих. Зрештою моє виття обірвалось, ц̌ вітер поніс його в небо...» [Кідрук 2016:513]. Лексикоморфологічний («крик» - «кричав» - «крики») та синонімічний («волав», «виття») повтори надають виразності зображеному, підсилюють емоційний вплив на реципієнта, акцентують на протиприродності смерті дитини.

Отже, ірраціональне продукує містичний модус роману «Зазирни в мої сни» Макса Кідрука. Оніризм моделює альтернативну модель світу, де можливо зануритись в таємничий простір підсвідомого, простежити наслідки клінічної смерті, що призвели до контактування двох людей в термінальному стані. Для дослідження процесів, які протікають на безсвідомому рівні психіки людини, митець використав неіснуючу технологію мозкового сканеру. Оніропростір роману створюють картини сновидінь, їх дешифровка, припущення про наслідки клінічної смерті, сомнамбулістичні блукання.

\section{БІБЛІОГРАФІЯ}

Бовсунівська 2015 - Бовсунівська Т. В. Жанрові модифікації сучасного роману / Тетяна Володимирівна Бовсунівська. - Харків : Діса плюс, 2015. 368 c. 
Кідрук 2016 - Кідрук М. Зазирни у мої сни : роман / Макс Кідрук. Харків : Клуб сімейного дозвілля, 2016. - 528 с.

Костецька 2015 - Костецька Л. О. Жанр трилеру в творчості М. Кідрука / Л. О. Костецька // Науковий вісник Миколаївського національного університету імені В. О. Сухомлинського. Філологічні науки. (літературознавство) : збірник наукових праць / за ред. О. С. Філатової. - № 2 (16), жовтень 2015. Миколаїв : МНУ імені В. О. Сухомлинського, 2015. - С. 133-137.

Хмелевская 2001 - Хмелевская Е. Н. Иррациональное в массовой культуре современной России: аспекты исследования : дис. ... канд. филос. наук : 24.00.01 / Елена Николаевна Хмелевская. - Ростов - на - Дону, 2010. $141 \mathrm{c}$. 